\title{
Comparative Study of Social Organizations' Support During Coronavirus Crisis
}

\author{
Anqi $\mathrm{Yu}^{1, *}$ \\ ${ }^{1}$ School of Economics and Management, Beijing Jiaotong University, Weihai, China, 264207 \\ *Corresponding author. Email:yaq5623265@163.com
}

\begin{abstract}
Since the outbreak of the coronavirus, countless people have been infected, diagnosed as severely ill, and even lost their lives as a result. Various countries have also adopted different epidemic prevention measures. This article compares the epidemic prevention measures and effects of China and the United States through literature reading. It can be concluded that the Chinese government's epidemic prevention work is very well in place, which has protected the lives and health of the Chinese people to a large extent. These measures are also worth promoting in more countries.
\end{abstract}

Keywords: coronavirus, epidemic prevention measures, China, the United States

\section{INTRODUCTION}

In face of the global Covid-19 crisis, China may not be the country that owns the least infected people, but it is one of the countries which coordinate excellently to overcome the crisis. During the Covid-19, China implemented the social distancing policy which other countries also adopted later. What's more, China also blocked one of the biggest cities, Wuhan, for 76 days, which is also a significant hub for delivering goods and materials to other cities. Compared with China, American and England also encompassed rapid growth of infected numbers but failed to totally command people to stay at home. Instead, these countries implemented a social distancing policy to suggest people stay at home. The social distancing policy was not as efficient and effective as previously thought by the government officials. For example, in June, the coronavirus in Texas was severe since there were more than 86 thousand infected people with a growth rate of $3.9 \%$. However, tubers still took to Texas's Comal River in New Braunfels on June 25. Nobody wore masks and thousands of people were crowded in the river. The reasons may be that China is a one-party dictatorship, which has more advantages towards command and control. "The advantages of the Chinese system have once again been demonstrated," as academic Qu Qingshan stated in People's Daily, the CPC's official mouthpiece. "China's battle against the epidemic showed that the $\mathrm{CPC}$, as China's ruling party, is by far the political party with the strongest governance capability in human history"[6]. Apart from this, social support played an important and indispensable role during the Covid-19.

\section{COMPARISON BETWEEN ACTION AND EFFECT OF SOCIAL POWER IN CHINA AND THE US}

Social forces include all kinds of enterprises, organizations, non-profit organizations, and individuals. During the Covid-19, all of them participated in fighting against the crisis and helping people. In terms of effect, different kinds of social forces played different roles. In China, some charities own outstanding advantages in collecting and delivering goods and materials, raising funds, and logistics management. Famous singers and dancers like Han Hong, took the advantage of their great influence to deliver information to the public so that ordinary people know which cities need masks or other supplies. Meanwhile, at the beginning of the outbreak, loads of college alumni associations and oversee Chinese actively coordinated resources abroad, purchased protection materials and equipment, and transferred them to domestic hospitals or cities. Some community members also played the role of volunteers to check body temperature and deliver vegetables and meats to isolated families[7]. Meanwhile, everyone returning from a high-risk area is quarantined. It is illegal to deliberately withhold movement information 
and reject themselves to be quarantined. With the protection of the law, most people followed rules and regulations.

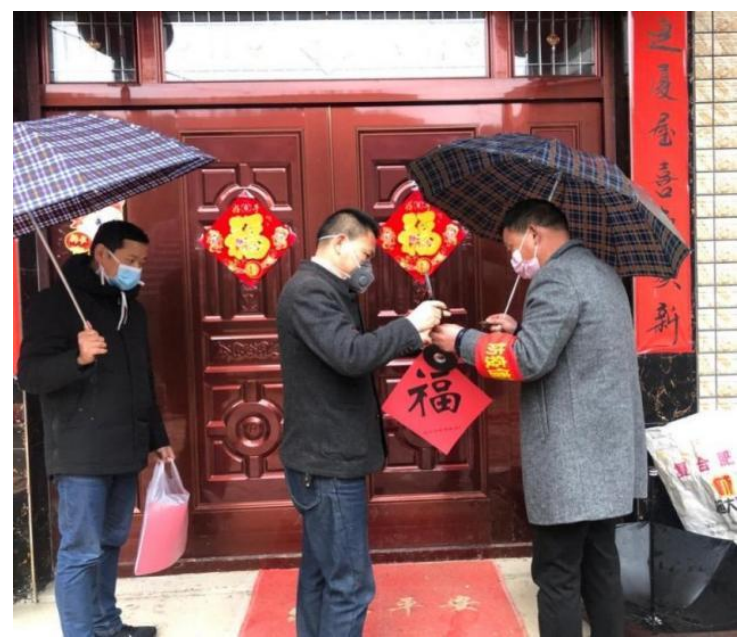

Figure 1.Implementation of the quarantine policy during the Chinese New Year

However, social organizations are also uncontrollable. Some social organizations resell materials in the epidemic. In April 2020, the Ministry of public security of China deployed a special attack action, which cracked 20 cases and arrested 42 suspect suspects, involving 34 million 450 thousand yuan. They bid up prices and make huge profits by hoarding, speculating in rising prices, and short selling.

Meanwhile, there were also negative internal and international public opinions arising on social media. In terms of internal negative public opinion, some people novel coronavirus pneumonia by using Weibo, WeChat, and other social channels, causing social panic. The government will resolutely investigate and deal with such public opinions that incite emotions. Those of a bad nature will be detained by the public security organs.

The global epidemic of novel coronavirus pneumonia has led to uncertainty and instability in the world. There is a narrative war and a public opinion war in the international public opinion field. After the outbreak, China actively assisted other countries, donated medical materials, dispatched expert medical teams, and regularly held video conferences to share the anti-epidemic experience with other countries. However, some American politicians label and stigmatize China around the source of the virus, and advocate "decoupling between China and the United States" and "the new cold war between China and the United States" against Sino US relations.
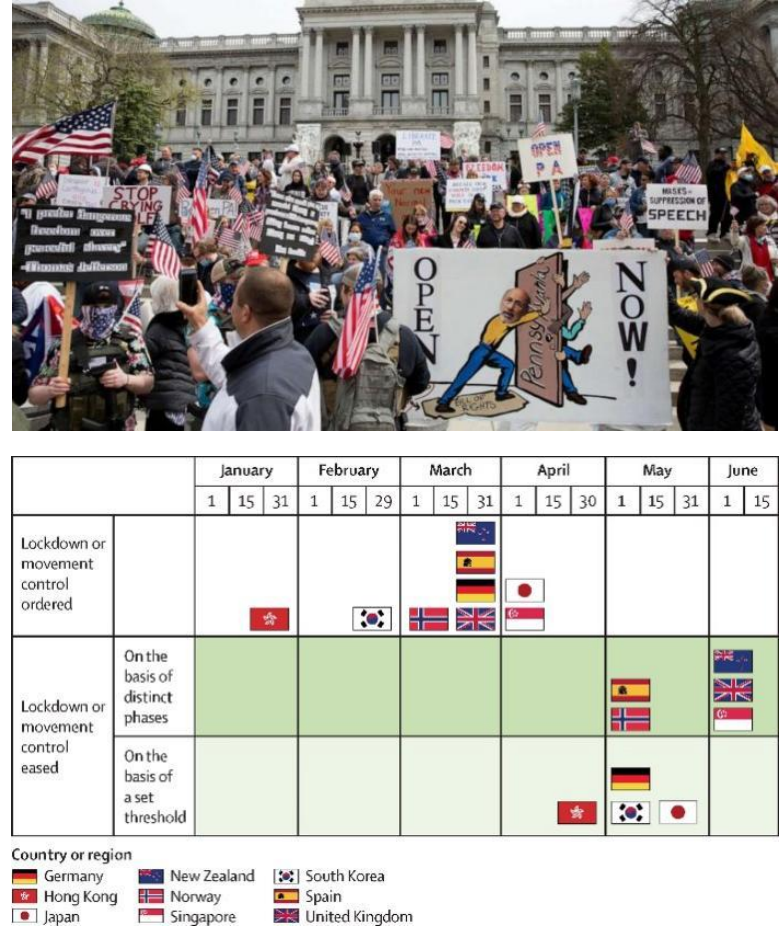

Figure 2Parade during the U.S. pandemic

In the US, things were more complicated. People took to the streets to protest the stay-at-home orders in Michigan, Minnesota, Maryland, California, Colorado, North Carolina, Virginia, Kentucky, and other states, in April 2020[1]. Since April 2020, demonstrations have broken out in many parts of the United States. In the process of expressing their demands, some demonstrators have gone overboard. For example, some people armed themselves to the full and barricaded themselves at the door of government office buildings, which has posed a certain threat to the national security of the United States and seriously affected the social order of the United States. The resistance of Americans significantly reduced the effect of social distancing policy and let the epidemic continue to spread.

Facts have proved that the US federal government system that decentralizes extensive power to the states is both a blessing and a curse. In good times, it allows local leaders to individually experiment with various public policy solutions, testing best practices that can be adopted across the country. However, in the case of a deadly pandemic, differently-paced response measures may not be enough and lead to some avoidable deaths and economic chaos. "Each governor is making his own decision, some people make the right decision, some people don't.

The US policy on economic stimulus is worth learning. The U.S. Congress passed a \$2 trillion COVID-19 relief bill, which includes direct cash payments to many Americans, expansion of unemployment assistance, assistance to states, medical facilities, and other public services, and assistance to 
industries that have been hit hardest. Support and grant loans to SMEs. If these companies avoid layoffs, these loans can be forgiven.

\section{LESSONS TO IMPROVE SOCIAL SUPPORT}

It is necessary to strengthen the coordination between government and society, and build a modern management system for major emergencies. A modern governance system for major emergencies should be led by the government to form an action mechanism in which the government, enterprises, social organizations, and the public interact and organically connect, to realize the complementary advantages of all parties. The key to constructing a modern governance system for major emergencies is coordinated by the government and society is to fully "authorize" under the dominant position of the government. To implement the goal of streamlining administration and delegating power, the key to social organizations is to give full play to their advantages and meet social needs.

Attach importance to publicity and guidance, and win the trust and support of the public. Social organizations should fully play an active role in responding to major emergencies. In addition to receiving strong government support and improving their capabilities, another very important aspect is to win the public's understanding, trust, and support of social organizations. This requires social organizations to make good use of traditional media and new media, and do a good job of propaganda and guidance.

It is also essential to improve the ability to respond to major emergencies. To improve the ability of social organizations to respond to major emergencies, especially for social organizations with emergency response functions, it relies on a set of preset emergency mechanisms, involving human mobilization, information communication, and material financing in emergencies.

\section{ISSUES REMAINS TO BE SOLVED}

Based on the historical records from past epidemic diseases, there is always a group of people who resist following the social distancing policy. It is argued that those people are either mistreated or mistrusted by the government and medical institutions that require more help and attention[2]. Government and social forces should pay attention to those people, who can be a threat to policy implementation in the long run.

It is argued that mortality was positively related to income inequality and negatively related to confidence in state institutions[3]. The situation in the United States is more serious, which is why Trump wants to restart the economy instead of home isolation. The United States is a country with a low savings rate. Americans live in debt. An ordinary American is surrounded by a lot of bills every day. If a normal American doesn't work for a month, his life will encounter great difficulties.

It is argued that when hospital staff was curing patients during Covid-19, they also suffer mental diseases such as depression, anxiety, insomnia, and psychological stress[2]. In this fight against the epidemic, the majority of medical staff have been fighting day and night, and some medical staff has unfortunately been infected by the virus, and some have even given their lives. Medical staff on the front line of epidemic prevention and control are exhausted physically and mentally, and early preventive intervention is of great significance to epidemic prevention and control work. The term exhaustion in English refers to extreme fatigue and burnout. Fatigue seriously affects the physical and mental health of medical staff, and thus affects the effectiveness of medical treatment.

\section{CONCLUSION}

During the epidemic, it is undeniable that national policies have affected the spread of the epidemic. However, the implementation of national policies also requires the cooperation of the general public and social forces, especially the cooperation of social organizations. The one-party autocracy adopted by China has certain advantages in implementing policies and controlling rumors. Therefore, under the protection of the law, the public is particularly opposed to the isolation policy. On the contrary, the cooperation of social organizations allows materials to be better deployed among different cities. Public figures such as celebrities can also disseminate donation information and channels through social media, to realize the difficulties of one party and the support from all parties.

Compared with China, the situation in the United States is quite different. Due to the emphasis on personal freedom, during the epidemic, some Americans did not fully realize the spread of the virus, gathered blindly, and did not wear masks. This has brought great and unnecessary pressure to medical treatment in the United States. Perhaps many Americans should not die in the new crown epidemic. In addition, due to the non-cooperation of the general public, the optimal policy for organizing the spread of the epidemic isolation, cannot be implemented. However, because there is only a social distancing policy, the impact on the US economy is relatively small. The economic stimulus plan released in the later period of the epidemic also effectively realized the economic recovery of the United States. This can be seen in the gradually decreasing unemployment rate. 


\section{REFERENCES}

[1]Bill H.(2020). Protests against coronavirus 'stay-at-home' orders spread across the country. Retrieved from https://abcnews.go.com/US/protests-coronavirus-st ay-home-orders-spread-country/story? $\mathrm{id}=70242988$

[2]Emeline H., Melisa T., Eva T., Devi S., Gabriel L., Kenji S., et al(2020). Lessons learnt from easing COVID-19 restrictions: an analysis of countries and regions in Asia Pacific and Europe. DOI: https://doi.org/10.1016/S0140-6736(20)32007-9

[3]Frank J. E., Anna S., Michael J.A.W.(2020). The trouble with trust: Time-series analysis of social capital, income inequality, and COVID-19 deaths in 84 countries. Social Science \& Medicine, Volume 263. Retrieved from https://doi.org/10.1016/j.socscimed.2020.113365

[4]Lai J, Ma S, Wang Y, et al. Factors Associated With Mental Health Outcomes Among Health Care Workers Exposed to Coronavirus Disease 2019. JAMA Netw Open. 2020;3(3):e203976. doi:10.1001/jamanetworkopen.2020.3976

[5]Paremoer L., Nandi S., Serag H., Baum F.. Covid-19 pandemic and the social determinants of health BMJ 2021; 372 :n129 doi:10.1136/bmj.n129

[6]Qingshan, Q.(2020, June 17). People's Daily: The strength of China's system in the fight against the epidemic is highlighted. Retrieved from http://opinion.people.com.cn/n1/2020/0617/c100331749118.html

[7]Qiwei, Z.(2020). The positive role of social forces in the national governance system from the perspective of the "anti-epidemic" practice. Retrieved from https://theory.gmw.cn/2020-02/28/content_336017 08.htm 